\title{
Influence of Different Irrigation Strategies on Yield and Water Use of Dry Bean (Phaseolus vulgaris L.) in Semi-Arid Zone
}

\author{
Nurcan Yavuz ${ }^{1, a, *}$ \\ ${ }^{1}$ Irrigation Department of Agriculture Faculty Selçuk University, 42130 Konya, Turkey \\ *Corresponding author
}

A R T I C L E I N F O B S T R A C T

Research Article

Increasing population and challenges among the sectors due to the climate change and incorrect water policy has increased the pressure on water resources. This situation being as a global crisis particularly in respect to the food security has accelerated productive utilization of water supplies. The aim of the current study with 2-year experiments was to identify the effect of different irrigation

Received : 14/06/2021 Accepted : 12/07/2021 interval and irrigation regimes on the yield and yield components of dry bean having greater than $50 \%$ of total world legumes production. In that experiment, two different irrigation interval, 7 and 14-day, and three different irrigation levels, ( $\mathrm{I}_{100}, \mathrm{I}_{75}$ and $\mathrm{I}_{50}$, were studied. In results, the maximum yield was obtained from 7-day irrigation interval, and $28 \%$ yield reduction was detected at 14 -day irrigation interval. In examine the irrigation levels, the highest yield was found at full irrigation ( $\mathrm{I}_{100}$ ), and increasing water stress caused significant yield reductions e.g. $21 \%$ and $49 \%$ for $\mathrm{I}_{75}$ and I50, respectively. The evapotranspiration and total applied water as an average of 2013-2014 were calculated as $533 \mathrm{~mm}$, and $450 \mathrm{~mm}$, respectively. In assessment of the both the combine year results, the ky value was determined as 1.59 , and this finding shows that dry bean crop is sensitive to the Keywords: Deficit irrigation Drip irrigation Irrigation water use efficiency Yield response factor water stress condition.

\section{Introduction}

The basic life activities have occurred by using the natural resources. The population growth and climate changes have increased utilization of such resources, but reduced their security. The some climate change indicators are surface heat rises, fluctuations in hydrological cycles, serious levels of salinization and desertification in agricultural lands. This situation known as global problem has forced to use both the soil and water resources more productive. In most environments, irrigation is vital important due to the high crop water use and lack of rainfall. The irrigated area should be increased by more than $20 \%$ and the irrigated crop yield should be increased by $40 \%$ by 2025 to secure the food for 8 billion people (Lascano and Sojka, 2007). The response of the crops to the water deficiency in region is very important role to play in planning of the production and management of the water resources. Plenty studies relevant to this issue (Ünlü et al., 2006; Aujla et al., 2007; Erdem et al., 2010; Yavuz et al., 2015; Yavuz et al., 2020) are hopeful for improving water use efficiency. The amounts of irrigation reduction is crop- dependent and generally accompanied by no or minor yield loss that increases the water use efficiency (Ahmadi et al., 2010).

The Konya plain having around $8 \%$ cultivated lands of Turkey and arid environment has very limited water supplies (Yavuz and Yavuz, 2021). The current available water bodies are almost $30 \%$ of the water demand for bringing under irrigation of the whole irrigable farmlands. Thus, water use in agriculture has to be diminished. In that issue, irrigation activities with high efficiency and growing low water consuming crops are prior strategies. In region, high water consuming crops including sugar beet, carrot, and maize are growth in most. Relatively low water consumption crops namely dry bean, melon and watermelon are also growth widely. Among those crops, bean is the top rank in respect production within the edible legumes. Dry bean having rich of protein and leafy resources is the perfect front crop for the wheat and sugar beet being growth intensely. It improves the fertility of soils by addition of nitrogen. 
The dry bean production was 21 million tons at 27 million hectares cultivated lands worldwide and was more than half of the total legumes production in accordance of 2019 records (FAOSTAT, 2021). Turkey has 1\% share with 225,000 tons production in the world (TÜIK, 2021). Dry bean farming in Middle Anatolia Region has to be performed under irrigation condition due to be insufficient rainfall amount as well as its none uniform distribution among the year. The average yield produced under irrigation $\left(2 \mathrm{Mg} \mathrm{ha}^{-1}\right)$ is 3-6 times higher than that of rain fed condition (0.28-0.56 $\mathrm{Mg} \mathrm{ha}^{-1}$ ) (Schwartz and Brick, 2015). According to the results of many studies, water deficiency during the growing cycles has a significant effect on bean yield (Bourgault et al., 2010; Boutraa and Sanders, 2001; Munoz-Perea et al., 2006; Ninou et al., 2013; Ucar et al., 2009; Wakrim et al., 2005; Topak et al., 2009). Efetha et al. (2011) noticed significant increase in average dry bean seed yield and in WUE for higher frequently irrigated treatments compared to less frequently irrigated treatments, therefore recommended keeping the majority of roots moist to optimize yield and water use efficiency (WUE). Being a shallow-rooted crop, dry bean plants extract $85 \%$ of their water from the upper $0.40 \mathrm{~m}$ of the soil profile (Yonts and Nuland, 1997) so frequent and less water application will result more effective irrigation strategy. In the light of such outcome, drip irrigation technique could lead to high irrigation water use efficiency, IWUE, for bean crop.

The aim of the current research, therefore, was to determine effect of different irrigation frequency and irrigation regimes on yield, yield components and water probability of drip irrigated dry bean crop. The most of the studies are relevant to the bean cultivars and their adaptation performance in Turkey. Thus, it will be highly meaningful to determine the water-yield relationships and optimal irrigation scheduling of dry bean crop.

\section{Material and Methods}

\section{Site Description}

This experiment was performed at Research Farm of Agricultural faculty, University of Selçuk, Konya-Turkey during the periods 2013-2014. The site is around $1006 \mathrm{~m}$ above the sea level having $38^{\circ} 05^{\prime}$ North latitude as well as $32^{\circ} 36^{\prime}$ East longitude.

Some climate data during the vegetation period for the both years were obtained from automatic meteorology station (Davis Vantage Pro2) mounted at research site. The vegetation cycles, between seed sowing and harvest, for 2013 and 2014 were 107-day and 103-day. The rainfall amounts for those vegetation periods of 2013, and 2014 were measured as $60.2 \mathrm{~mm}$, and $73.8 \mathrm{~mm}$, respectively. The daily mean maximum and daily mean minimum temperatures for both the years in vegetation cycles were found $29^{\circ} \mathrm{C}$ and $15^{\circ} \mathrm{C}$, respectively (Figure 1-a,b). The climate values measured at experimental years were almost similar to the long-year average of the region.

The soil of research site is light color, clay dominating through the profile, no problems relevant to the drainage and salinity. The some physical and chemical characteristics of research soil were given at Table 1. The bulk density and organic matter contents of research soil varied from 1.26 to $1.30 \mathrm{~g} \mathrm{~cm}^{-3}$, and from $0.84 \%$ to $1.88 \%$, respectively. The available water capacity, AWC, of upper $90 \mathrm{~cm}$ soil depth was calculated as $125.4 \mathrm{~mm}$.
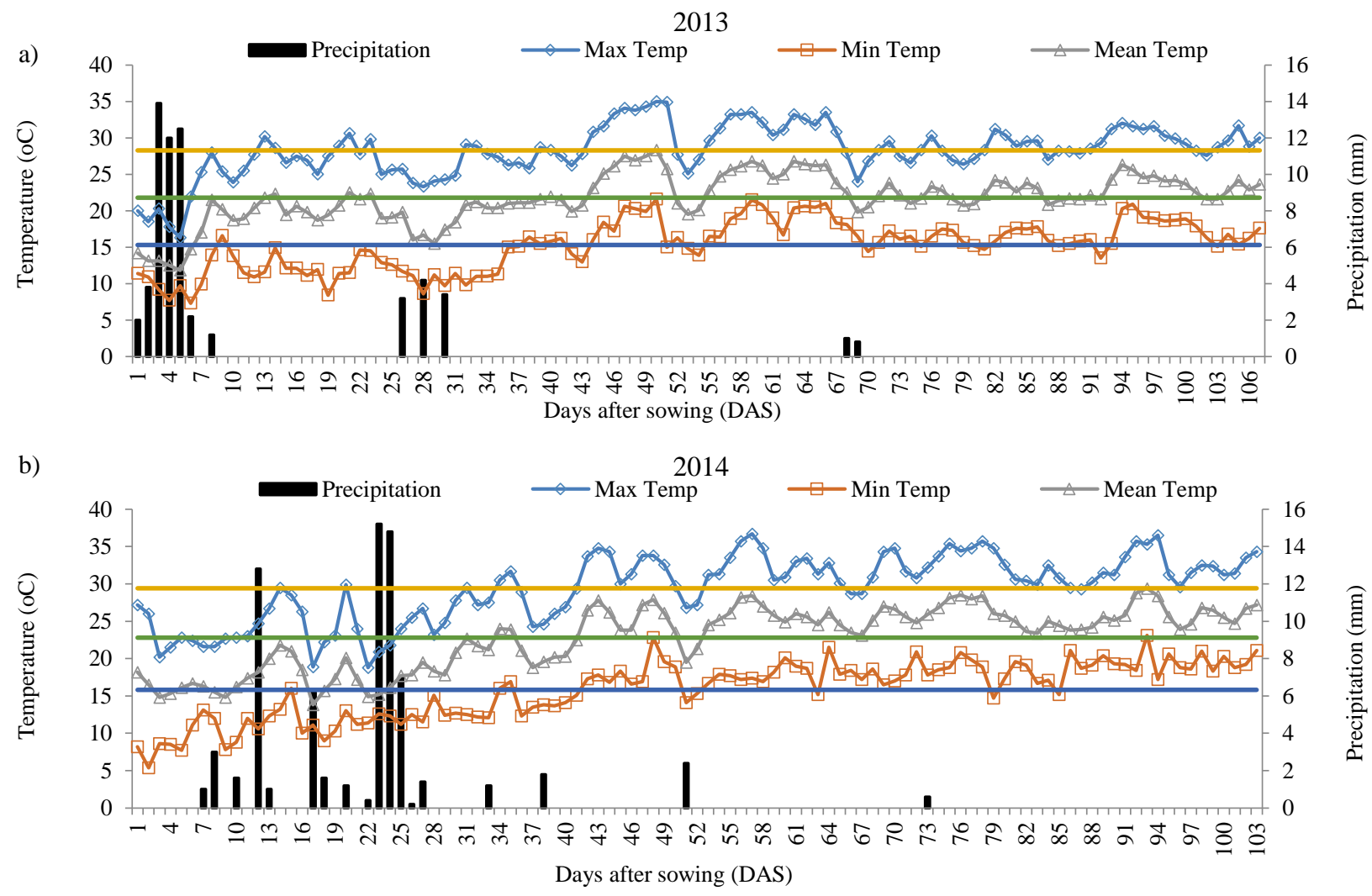

Figure 1 . Some climate data during the vegetation cycle of dry bean $(a, 2013 ; b, 2014)$ 
Table 1. Some physical and chemical properties of the trial area soil

\begin{tabular}{|c|c|c|c|c|c|c|c|c|c|c|}
\hline \multirow{2}{*}{$\begin{array}{c}\text { Soil } \\
\text { depth } \\
(\mathrm{cm})\end{array}$} & \multirow{2}{*}{$\begin{array}{l}\text { Textur } \\
\text { e class }\end{array}$} & \multirow{2}{*}{$\begin{array}{c}\text { Organic } \\
\text { materials } \\
(\%)\end{array}$} & \multirow[t]{2}{*}{$\mathrm{pH}$} & \multirow{2}{*}{$\begin{array}{c}\text { Bulk } \\
\text { density } \\
\left(\mathrm{g} \mathrm{cm}^{-3}\right)\end{array}$} & \multicolumn{2}{|c|}{ Field capacity } & \multicolumn{2}{|c|}{ Wilting point } & \multicolumn{2}{|c|}{$\begin{array}{l}\text { Available soil } \\
\text { water content }\end{array}$} \\
\hline & & & & & $\mathrm{m}^{3} \mathrm{~m}^{-3}$ & $\mathrm{~mm}$ & $\mathrm{~m}^{3} \mathrm{~m}^{-3}$ & $\mathrm{~mm}$ & $\mathrm{~m}^{3} \mathrm{~m}^{-3}$ & $\mathrm{~mm}$ \\
\hline $0-30$ & SICL & 1.88 & 7.75 & 1.30 & 0.376 & 112.8 & 0.226 & 67.8 & 0.150 & 45.0 \\
\hline $30-60$ & SIC & 1.36 & 7.78 & 1.28 & 0.374 & 112.2 & 0.236 & 70.8 & 0.138 & 41.4 \\
\hline $60-90$ & $\mathrm{C}$ & 0.84 & 7.78 & 1.26 & 0.368 & 110.4 & 0.238 & 71.4 & 0.130 & 39.0 \\
\hline & & & & Tot & $0-90 \mathrm{~cm})$ & 335.4 & & 210.0 & & 125.4 \\
\hline
\end{tabular}

SICL: Silty clay loam, SIC: Silty clay, and C: Clay

Table 2. Irrigation treatments applied in the experiment

\begin{tabular}{l|l}
\hline Irrigation intervals & Irrigation treatments \\
\hline & $\mathrm{S}_{7} \mathrm{I}_{100}$ : Applying irrigation water until reach the field capacity again the decreasing soil \\
& moisture at $0-90 \mathrm{~cm}$ soil depth in 7 days of irrigation interval \\
& $\mathrm{S}_{7} \mathrm{I}_{75}$ : Applying $75 \%$ of the irrigation water given to the $\mathrm{S}_{7} \mathrm{I}_{100}$ treatment \\
& $\mathrm{S}_{7} \mathrm{I}_{50}$ : Applying $50 \%$ of the irrigation water given to the $\mathrm{S}_{7} \mathrm{I}_{100}$ treatment \\
& $\mathrm{S}_{14} \mathrm{I}_{100}$ : Applying irrigation water until reach the field capacity again the decreasing soil \\
& moisture at 0-90 cm soil depth in 14 days of irrigation interval \\
& $\mathrm{S}_{14} \mathrm{I}_{75}$ : Applying $75 \%$ of the irrigation water given to the $\mathrm{S}_{14} \mathrm{I}_{100}$ treatment \\
& $\mathrm{S}_{14} \mathrm{I}_{50}$ : Applying $50 \%$ of the irrigation water given to the $\mathrm{S}_{14} \mathrm{I}_{100}$ treatment \\
\hline
\end{tabular}

Supply of Irrigation Water and Design of the Drip Irrigation System

Irrigation water was taken from the deep well-being far away from the $50 \mathrm{~m}$ to the experimental area. The irrigation water quality was determined as $\mathrm{C}_{2} \mathrm{~S}_{1}$. Irrigation water was applied to the plots by drip irrigation system.

The drip irrigation systems had followings components; PE lateral tube having $16 \mathrm{~mm}$ diameter producing $4 \mathrm{~L} \mathrm{~h}^{-1}$ under $100 \mathrm{kPa}$ working pressure, PE 63 $\mathrm{mm}$ main line, and PE $32 \mathrm{~mm}$ manifold. Emitter space was chosen as $40 \mathrm{~cm}$ by considering soil properties as well as emitter flow rate. The $3 / 4$ inch water meter at entrance of parcel was used for determination of the applied water to the parcels.

\section{Irrigation Treatments and Plot Design}

The experiment was carried out Randomized Block Factorial Design with three repetitions. The two different irrigation intervals namely 7 and 14-day were considered, and three different water levels of $\mathrm{I}_{100}, \mathrm{I}_{75}$ and $\mathrm{I}_{50}$ for each irrigation interval were applied. The farmers of the region, who are engaged in agricultural production under drip irrigation conditions, use irrigation intervals of 7-10 days for dry beans because they irrigate other plants such as sugar beet, sunflower and maize from the same deep-well located their farm land. On the other hand, farmers using common water resources such as cooperative wells and dams often have to wait two weeks before they can irrigate their crops. For all these reasons, 7 and 14 days irrigation intervals were used in the present study, considering the farmer practices and irrigation management in the region. In the study, the six treatments were designated as $\mathrm{S}_{7} \mathrm{I}_{100}$, $\mathrm{S}_{7} \mathrm{I}_{75}, \mathrm{~S}_{7} \mathrm{I}_{50}, \mathrm{~S}_{14} \mathrm{I}_{100}, \mathrm{~S}_{14} \mathrm{I}_{75}$ and $\mathrm{S}_{14} \mathrm{I}_{50}$ (Table 2).

The day before the sowing day of bean seeds, parcels were done and drip irrigation system was installed to the research parcels. The length of the parcel was $5 \mathrm{~m}$ with 5 crop rows in each parcel. The lateral tubes having $5 \mathrm{~m}$ in long and $50 \mathrm{~cm}$ in space were mounted to the parcels. The crop row space and space on plants were $50 \mathrm{~cm}$, and $8 \mathrm{~cm}$, respectively with 25 plant per $\mathrm{m}^{2}$. The space between blocks and between parcels was constant as $2.5 \mathrm{~m}$.

\section{Agricultural Practices}

Nitrogen and phosphorus were applied as basal fertilization and incorporated into the soil with a disk harrow just before seed sowing. The application rates were $80 \mathrm{~kg} \mathrm{~N}$ $\mathrm{ha}^{-1}$ as $\left(\mathrm{NH}_{4}\right)_{2} \mathrm{SO}_{4}$ and $50 \mathrm{~kg} \mathrm{P}_{2} \mathrm{O}_{5} \mathrm{ha}^{-1}$ as superphosphate. Dry bean seeds were hand-planted on 11 May 2013 and 16 May 2014. In order to ensure a homogeneous germination and emergence immediately after sowing, irrigation water of 20 $\mathrm{mm}$ and $15 \mathrm{~mm}$ was applied to all treatments in 2013 and 2014 , respectively. Protections from the disease and insects were performed at required times during the vegetation cycles. The outer edges of parcels were ignored just prior to the harvest, and harvests were done 25 August (107 DAS, Days after sowing), and 26 August (103 DAS) for 2013, and 2014, respectively.

In order to determine yield components such as number of pods per plant, number of seeds per pod and 1000-seed weight, twenty plants were selected and marked in each plot in both experimental years. Yield components of each treatment were calculated by considering the number of pods, seed numbers and seed weights in these selected plants at harvest.

\section{Irrigation Water, evapotranspiration and $I_{r c}$}

The applied water for the treatments was performed as stated at Table 2. In that regard, applied water for irrigation treatments at 7-day irrigation interval was considered reduced moisture amount at $0-90 \mathrm{~cm}$ rooting depth of $\mathrm{S}_{7} \mathrm{I}_{100}$ treatment. Irrigation water amount for irrigation treatments at 14-day irrigation interval was considered reduced moisture amount at $0-90 \mathrm{~cm}$ rooting depth of $\mathrm{S}_{14} \mathrm{I}_{100}$ treatment (Table 2). Soil water content was measured with profile probe (model PR2, Delta-T, UK). The soil water content was recorded at sowing, at every 7-day interval and at the time of harvesting. One access tube was installed in every treatment.

Crop water use for treatments was calculated by using water budget basis by using Eqn.1 as suggested by James (1988).

$$
\mathrm{ET}=\mathrm{I}+\mathrm{R}-\mathrm{D}_{\mathrm{P}}+\mathrm{C}_{\mathrm{P}}-\mathrm{R}_{\mathrm{F}} \pm \Delta \mathrm{S}
$$


ET= Evapotranspiration $(\mathrm{mm}), \mathrm{I}=$ Depth of applied water $(\mathrm{mm}), \mathrm{R}=$ Efficient rainfall $(\mathrm{mm}), \mathrm{D}_{\mathrm{p}}=$ Water loss by deep percolation through lower parts of rooting depth $\mathrm{mm}$ ), $\mathrm{C}_{\mathrm{p}}=$ Capillary movement to the rooting area $(\mathrm{mm}), \mathrm{R}_{\mathrm{f}}=$ Losses via surface runoff $(\mathrm{mm}), \Delta \mathrm{S}=$ changes soil water content at root zone depth (mm).

In equation, I value from applied water amount and $\mathrm{R}$ value from portable climate station installed at research area, and Dp value from soil samples taken by auger from the 90$120 \mathrm{~cm}$ soil depth by gravimetric method were obtained. None deep percolation was present below the $90 \mathrm{~cm}$ soil depth since the amount of water application for whole treatment never exceeded the field capacity moisture level of soil. The soil of research area is deep without any drainage and salinity problems so there was no capillary movement from the water table thus $\mathrm{Cp}$ value was ignored in the calculations. $\Delta \mathrm{S}$ was obtained from the soil moisture measurements by profile probe. Drip irrigation system was designated and managed accurately so Rf value was counted out in calculations due to the none occurrence of surface runoff.

The contribution or compensating ratio of irrigation water to the evapotranspiration was calculated by following eqn. (Howell et al., 1990);

$$
\mathrm{I}_{\mathrm{rc}}=\frac{\mathrm{I}}{\mathrm{ET}} \times 100
$$

Where; $\mathrm{I}_{\mathrm{rc}}$, irrigation water contribution percentage of crop water uses; I, total irrigation water depth $(\mathrm{mm})$ and ET, crop water use in vegetation cycles.

\section{Yield Response Factor (ky), WUE and IWUE}

The relationships between evapotranspiration and seed yield was determined by using following equation derived by Doorenbos and Kassam (1979).

$$
\left[1-\frac{\mathrm{Ya}}{\mathrm{Ym}}\right]=\mathrm{ky}\left[1-\frac{\mathrm{ETa}}{\mathrm{ETm}}\right]
$$

$\mathrm{Ya}=$ Real yield ( $\mathrm{kg} / \mathrm{ha}), \mathrm{Ym}=$ the highest yield $(\mathrm{kg} / \mathrm{ha})$, $\mathrm{ky}=$ Yield response factor, $\mathrm{ETa}=$ Real evapotranspiration $(\mathrm{mm}) \mathrm{ETm}=$ The highest evapotranspiration $(\mathrm{mm})$.

Water use efficiency (WUE) was calculated by dividing seed yield $(\mathrm{kg} / \mathrm{ha})$ obtained from the treatments to the evapotranspiration $\left(\mathrm{m}^{3} / \mathrm{ha}\right)$; and irrigation water use efficiency (IWUE) was determined in ratio of seed yield $(\mathrm{kg} / \mathrm{ha})$ to the applied irrigation water amount $\left(\mathrm{m}^{3} / \mathrm{ha}\right)$.

\section{Statistical Analysis}

The suitability of yield and yield components obtained from the both the two years (2013-2014) for the combine analyze was decided by using the homogeneity tests ( $\mathrm{F}$ test). In accordance of homogeneity test results, both the experimental years were assessed individually since error variance of yield and yield parameters were not found homogeny in the year basis. Variance analysis was performed to the data obtained from the experiments in order to determine the differences between yield and yield components. The characteristics having significant different statistically at $5 \%$ significant level were grouped by Duncan test. The both the variance and Duncan tests were done via SPSS 22.0 computer program.

\section{Results and Discussion}

\section{Irrigation Water Amount and ET}

The applied water amounts and irrigation time were given for the both the experimental years separately (Table $3,4)$. In both experimental years, the numbers of irrigation after the starting of the scheduled irrigations for 7-day and 14-day irrigation intervals were 9 and 5, respectively. The irrigation water amounts for treatments in first and second growing seasons varied from 216 to $456 \mathrm{~mm}$, and from 208 to $445 \mathrm{~mm}$, respectively. In both the experimental years, there was around $10 \%$ reduction in applied water amount in treatment with 14-day irrigation interval by comparison to treatment with 7-day irrigation interval. Total amount of rainfall during the 2013 growing season was recorded as $60.2 \mathrm{~mm}$, and it was found as $73.8 \mathrm{~mm}$ for 2014 vegetation cycle. The scheduled irrigation program was about two months in both experimental years, and the rainfall amount was very little in that period (Figure 1a, b) so crop water needs were met by irrigation. The maximum evapotranspiration was $539.0 \mathrm{~mm}$ for 2013 and $527.6 \mathrm{~mm}$ for 2014 at $\mathrm{S}_{7} \mathrm{I}_{100}$ treatment (Table 5). In study conducted by Sezen et al. (2005) about the effect of drip irrigation on growth, yield and quality of fresh bean under Mediterranean environment, the applied water of $50 \%$, $75 \%$, and $100 \%$ of cumulative evaporation measured from the Class A Pan with irrigation intervals of 2-3 day, 5-7 day, 8-9 day, and 10-12 were considered. They reported applied water between 202 and $341 \mathrm{~mm}$ with seasonal irrigation water amount between $261 \mathrm{~mm}$ and $338 \mathrm{~mm}$.

\begin{tabular}{|c|c|c|c|c|c|c|}
\hline \multirow{3}{*}{ Irrigation date } & \multicolumn{6}{|c|}{ Irrigation Intervals } \\
\hline & \multicolumn{3}{|c|}{$\begin{array}{c}\text { 7-day } \\
\text { Irrigation levels }\end{array}$} & \multicolumn{3}{|c|}{$\begin{array}{c}\text { 14-day } \\
\text { Irrigation levels }\end{array}$} \\
\hline & $\mathrm{I}_{100}$ & $\mathrm{I}_{75}$ & $\mathrm{I}_{50}$ & $\mathrm{I}_{100}$ & $\mathrm{I}_{75}$ & $\mathrm{I}_{50}$ \\
\hline 11 May $^{*}$ & 20 & 20 & 20 & 20 & 20 & 20 \\
\hline 18 June $^{* *}$ & 72 & 54 & 36 & 72 & 54 & 36 \\
\hline 25 June & 29 & 22 & 15 & & & \\
\hline 2 July & 38 & 29 & 19 & 64 & 48 & 32 \\
\hline 9 July & 43 & 32 & 22 & & & \\
\hline 16 July & 51 & 38 & 26 & 81 & 61 & 41 \\
\hline 23 July & 58 & 44 & 29 & & & \\
\hline 30 July & 57 & 43 & 29 & 98 & 74 & 49 \\
\hline 6 Aug & 48 & 36 & 24 & & & \\
\hline 13 Aug & 40 & 30 & 20 & 76 & 57 & 38 \\
\hline Total irrigation water $(\mathrm{mm})$ & 456 & 347 & 238 & 411 & 313 & 216 \\
\hline
\end{tabular}

Table 3. Irrigation water amounts (mm) applied treatments in 2013 
Table 4. Irrigation water amounts (mm) applied treatments in 2014

\begin{tabular}{|c|c|c|c|c|c|c|}
\hline \multirow{3}{*}{ Irrigation date } & \multicolumn{6}{|c|}{ Irrigation Intervals } \\
\hline & \multicolumn{3}{|c|}{$\begin{array}{c}\text { 7-day } \\
\text { Irrigation levels }\end{array}$} & \multicolumn{3}{|c|}{$\begin{array}{c}\text { 14-day } \\
\text { Irrigation levels }\end{array}$} \\
\hline & $\mathrm{I}_{100}$ & $\mathrm{I}_{75}$ & $\mathrm{I}_{50}$ & $\mathrm{I}_{100}$ & $\mathrm{I}_{75}$ & $\mathrm{I}_{50}$ \\
\hline 16 May $^{*}$ & 15 & 15 & 15 & 15 & 15 & 15 \\
\hline 20 June** & 65 & 49 & 33 & 65 & 49 & 33 \\
\hline 27 June & 32 & 24 & 16 & - & - & - \\
\hline 4 July & 35 & 26 & 18 & 61 & 46 & 31 \\
\hline 11 July & 46 & 35 & 23 & - & - & - \\
\hline 18 July & 50 & 38 & 25 & 88 & 66 & 44 \\
\hline 25 July & 53 & 40 & 27 & - & - & - \\
\hline $1 \mathrm{Aug}$ & 55 & 41 & 28 & 92 & 69 & 46 \\
\hline 8 Aug & 50 & 38 & 25 & - & - & - \\
\hline 15 Aug & 44 & 33 & 22 & 80 & 60 & 40 \\
\hline Total irrigation water (mm) & 445 & 338 & 230 & 401 & 305 & 208 \\
\hline
\end{tabular}

*: Irrigation water given for germination and emergence; **: Start date of scheduled irrigations

Table 5. Total irrigation water amount applied, the precipitation, the changes in soil moisture content between planting and harvesting dates $(\Delta S)$, crop evapotranspiration $(E T c)$, and irrigation water compensation $\left(\mathrm{I}_{\mathrm{rc}}\right)$.

\begin{tabular}{|c|c|c|c|c|c|c|c|}
\hline \multirow[b]{2}{*}{ Year } & \multicolumn{2}{|c|}{ Treatments } & \multirow{2}{*}{$\begin{array}{c}\text { Irrigation } \\
\text { water } \\
(\mathrm{mm})\end{array}$} & \multirow[b]{2}{*}{$\begin{array}{l}\text { Precipitation } \\
\quad(\mathrm{mm})\end{array}$} & \multirow[b]{2}{*}{$\begin{array}{c}\Delta \mathrm{S} \\
(\mathrm{mm})\end{array}$} & \multirow[b]{2}{*}{$\begin{array}{l}\text { ETc } \\
(\mathrm{mm})\end{array}$} & \multirow[b]{2}{*}{$\begin{array}{l}\mathrm{I}_{\mathrm{rc}} \\
(\%)\end{array}$} \\
\hline & $\begin{array}{l}\text { Irrigation } \\
\text { intervals }\end{array}$ & $\begin{array}{c}\text { Irrigation } \\
\text { levels }\end{array}$ & & & & & \\
\hline \multirow{6}{*}{2013} & \multirow{3}{*}{ 7-day $\left(S_{7}\right)$} & $\mathrm{I}_{100}$ & 456 & 60.2 & 22.8 & 539.0 & 84.6 \\
\hline & & $\mathrm{I}_{75}$ & 347 & 60.2 & 34.1 & 441.3 & 78.6 \\
\hline & & $\mathrm{I}_{50}$ & 238 & 60.2 & 63.0 & 361.2 & 65.9 \\
\hline & \multirow{3}{*}{ 14-day $\left(\mathrm{S}_{14}\right)$} & $\mathrm{I}_{100}$ & 411 & 60.2 & 12.5 & 483.7 & 85.0 \\
\hline & & $\mathrm{I}_{75}$ & 313 & 60.2 & 28.8 & 402.0 & 77.9 \\
\hline & & $\mathrm{I}_{50}$ & 216 & 60.2 & 48.1 & 324.3 & 66.6 \\
\hline \multirow{6}{*}{2014} & \multirow{3}{*}{ 7-day $\left(\mathrm{S}_{7}\right)$} & $\mathrm{I}_{100}$ & 445 & 73.8 & 8.8 & 527.6 & 84.3 \\
\hline & & $\mathrm{I}_{75}$ & 338 & 73.8 & 26.7 & 438.0 & 77.1 \\
\hline & & $\mathrm{I}_{50}$ & 230 & 73.8 & 49.8 & 353.6 & 65.0 \\
\hline & \multirow{3}{*}{14 -day $\left(\mathrm{S}_{14}\right)$} & $\mathrm{I}_{100}$ & 401 & 73.8 & 5.9 & 480.7 & 83.4 \\
\hline & & $\mathrm{I}_{75}$ & 305 & 73.8 & 14.8 & 393.1 & 77.5 \\
\hline & & $\mathrm{I}_{50}$ & 208 & 73.8 & 36.5 & 318.3 & 65.3 \\
\hline
\end{tabular}

Gençoğlan et al. (2006) examined two different drip irrigation systems (SDI, SPRD), and four different croppan coefficient namely $\mathrm{Kcp} 1=0.6, \mathrm{Kcp} 2=0.8, \mathrm{Kcp} 3=1.0$ and $\mathrm{Kcp} 4=1.2$ for bean crop, and they calculated maximum irrigation water of $437 \mathrm{~mm}$ and maximum evapotranspiration of $470 \mathrm{~mm}$ at SDIKcp4 treatment. Şehirali et al. (2005) calculated $732 \mathrm{~mm}$ seasonal crop water use of bean from the treatment meeting whole crop water requirement. The reasons behind the differences of results could be variations in environmental and soil conditions in the research regions.

The most portion of the crop water use is met by irrigation in arid and semi-arid ecologies such as Konya. The $I_{\mathrm{rc}}$ values defined as irrigation water compensating percentage of evapotranspiration varied from $66.6 \%$ to $84.6 \%$ in 2013 , and from $65.3 \%$ to $84.3 \%$ in 2014 (Table 5). Following $I_{r c}$ values were reported in studies about water-yield relationships for some crops performed at Konya: $88 \%$ for sugar beet (Topak et al., 2016), 82\% for pumpkin (Yavuz et al., 2015), 81\%-84 for melon (Yavuz, 2021; Yavuz et al., 2021), higher than $85 \%$ for watermelon and sunflower (Yavuz et al., 2019; Yavuz et al., 2020).

\section{Seed Yield and Yield Components}

In both the experimental years, the highest seed yield (2088 $\mathrm{kg} \mathrm{ha}^{-1}$ in $2013,2120 \mathrm{~kg} \mathrm{ha}^{-1}$ in 2014) was obtained from $\mathrm{S}_{7} \mathrm{I}_{100}$ treatment having maximum evapotranspiration (Table 6,7). In results of the variance analysis performed for seed yields, although irrigation interval and irrigation doses was found significant at $99 \%$ significant level $(\mathrm{P}<0.01)$, irrigation interval $\mathrm{x}$ irrigation doses interaction was found not significant statistically (Table 6, 7). Among the irrigation interval treatments, the maximum yield was found at 7 -day irrigation interval, and $28 \%$ yield loss was determined at 14-day irrigation interval. In examine the irrigation level treatments, full irrigation, $\mathrm{I}_{100}$, led to maximum yield, and increasing the water stress caused notable yield losses such as $21 \%$ at $\mathrm{I}_{75}$, and $49 \%$ at $\mathrm{I}_{50}$. Ünlükara et al. (2018) performed a research for dry bean under semi-arid climate, and they met the $100 \%, 75 \%, 50 \%$ and $25 \%$ of the 'replenishments of soil moisture content. The S25 treatment resulted $62 \%$ yield loss by comparison to $\mathrm{S} 100$ treatment having maximum yield. Similarly, Yonts et al. (2018) also stated moderate water stress caused $30 \%$ yield loss for dry bean. In contrast, Şimşek et al. (2011) stated that $25 \%$ water deficiency at pod formation stage of dry bean had no significant yield reduction; and Uçar et al. (2009) reported that $25 \%$, even $50 \%$ water deficiency could be tolerable at such stage of dry bean. Satriani et al. (2015), performed a study for bean genotype having not high sensitivity to the water stress. They observed none yield reduction at $50 \%$ ETc application. 
Table 6. Mean comparisons for the seed yield, yield components, WUE and IWUE in dry bean under different irrigation intervals and levels in 2013

\begin{tabular}{|c|c|c|c|c|c|c|c|}
\hline \multicolumn{2}{|c|}{ Treatments } & $\begin{array}{l}\text { Seed yield } \\
\left(\mathrm{kg} \mathrm{ha}^{-1}\right)\end{array}$ & $\begin{array}{c}\text { Number of pods } \\
\text { per plant }\end{array}$ & $\begin{array}{c}\text { Number of } \\
\text { seeds per pod }\end{array}$ & $\begin{array}{l}\text { 1000-seed } \\
\text { weight }(\mathrm{g})\end{array}$ & $\begin{array}{c}\text { WUE } \\
\left(\mathrm{kg} \mathrm{m}^{-3}\right)\end{array}$ & $\begin{array}{c}\text { IWUE } \\
\left(\mathrm{kg} \mathrm{m}^{-3}\right)\end{array}$ \\
\hline \multicolumn{8}{|c|}{ Irrigation interval $(\mathrm{S})$} \\
\hline \multirow{2}{*}{\multicolumn{2}{|c|}{$\begin{array}{l}\text { 7-day }\left(\mathrm{S}_{7}\right) \\
\text { 14-day }\left(\mathrm{S}_{14}\right)\end{array}$}} & $1665^{\mathrm{a}}$ & $9.9^{\mathrm{a}}$ & $2.4^{\mathrm{a}}$ & $248.5^{\mathrm{a}}$ & $0.37^{\mathrm{a}}$ & $0.48^{\mathrm{a}}$ \\
\hline & & $1194^{\mathrm{b}}$ & $8.9^{\mathrm{b}}$ & $1.9^{\mathrm{b}}$ & $191.2^{\mathrm{b}}$ & $0.29^{\mathrm{b}}$ & $0.38^{\mathrm{b}}$ \\
\hline \multicolumn{8}{|c|}{ Irrigation level (I) } \\
\hline \multirow{3}{*}{\multicolumn{2}{|c|}{$\begin{array}{l}\mathrm{I}_{100} \\
\mathrm{I}_{75} \\
\mathrm{I}_{50}\end{array}$}} & $1872^{\mathrm{a}}$ & $10.8^{\mathrm{a}}$ & $2.5^{\mathrm{a}}$ & $253.6^{\mathrm{a}}$ & $0.36^{\mathrm{a}}$ & 0.43 \\
\hline & & $1464^{\mathrm{b}}$ & $9.4^{\mathrm{b}}$ & $2.2^{\mathrm{b}}$ & $234.1^{\mathrm{b}}$ & $0.34^{\mathrm{a}}$ & 0.44 \\
\hline & & $952^{\mathrm{c}}$ & $8.0^{\mathrm{c}}$ & $1.8^{\mathrm{c}}$ & $171.8^{\mathrm{c}}$ & $0.28^{\mathrm{b}}$ & 0.42 \\
\hline & \multicolumn{6}{|c|}{ S X I } \\
\hline \multirow{3}{*}{ 7-day } & $\mathrm{I}_{100}$ & 2088 & $11.2^{\mathrm{a}}$ & 2.7 & 277.4 & 0.39 & 0.46 \\
\hline & $\mathrm{I}_{75}$ & 1742 & $9.5^{\mathrm{b}}$ & 2.5 & 263.8 & 0.39 & 0.50 \\
\hline & $\mathrm{I}_{50}$ & 1165 & $9.1^{\mathrm{b}}$ & 2.0 & 204.2 & 0.32 & 0.49 \\
\hline \multirow{3}{*}{ 14-day } & $\mathrm{I}_{100}$ & 1657 & $10.5^{\mathrm{a}}$ & 2.3 & 229.8 & 0.34 & 0.40 \\
\hline & $\mathrm{I}_{75}$ & 1186 & $9.3^{b}$ & 1.8 & 204.3 & 0.29 & 0.38 \\
\hline & $\mathrm{I}_{50}$ & 740 & $7.0^{\mathrm{c}}$ & 1.7 & 139.4 & 0.23 & 0.34 \\
\hline \multicolumn{8}{|c|}{ Significance } \\
\hline \multirow{3}{*}{\multicolumn{2}{|c|}{$\begin{array}{l}\text { Irrigation interval (S) } \\
\text { Irrigation level (I) } \\
\text { S X I }\end{array}$}} & $* *$ & $* *$ & $* *$ & $* *$ & $* *$ & $* *$ \\
\hline & & $* *$ & $* *$ & $* *$ & $* *$ & $* *$ & $\mathrm{~ns}$ \\
\hline & & ns & $* *$ & ns & ns & ns & ns \\
\hline
\end{tabular}

ns: not significant; *: $\mathrm{P}<0.05 ; * *: \mathrm{P}<0.01$; Lowercase letters indicate significant differences between treatments according to Duncan's test $(\mathrm{P}<0.05)$.

Table 7. Mean comparisons for the seed yield, yield components, WUE and IWUE in dry bean under different irrigation intervals and levels in 2014

\begin{tabular}{|c|c|c|c|c|c|c|c|}
\hline \multicolumn{2}{|c|}{ Treatments } & $\begin{array}{c}\text { Seed yield } \\
\left(\mathrm{kg} \mathrm{ha}^{-1}\right)\end{array}$ & $\begin{array}{c}\text { Number of pods } \\
\text { per plant }\end{array}$ & $\begin{array}{c}\text { Number of seeds } \\
\text { per pod }\end{array}$ & $\begin{array}{l}\text { 1000-seed } \\
\text { weight }(\mathrm{g}) \\
\end{array}$ & $\begin{array}{c}\text { WUE } \\
\left(\mathrm{kg} \mathrm{m}^{-3}\right)\end{array}$ & $\begin{array}{c}\text { IWUE } \\
\left(\mathrm{kg} \mathrm{m}^{-3}\right)\end{array}$ \\
\hline \multicolumn{8}{|c|}{ Irrigation interval (S) } \\
\hline \multirow{2}{*}{\multicolumn{2}{|c|}{$\begin{array}{l}\text { 7-day }\left(\mathrm{S}_{7}\right) \\
\text { 14-day }\left(\mathrm{S}_{14}\right)\end{array}$}} & $1613^{\mathrm{a}}$ & $10.8^{\mathrm{a}}$ & 2.3 & $245.3^{\mathrm{a}}$ & $0.36^{\mathrm{a}}$ & $0.48^{\mathrm{a}}$ \\
\hline & & $1151^{\mathrm{b}}$ & $8.7^{\mathrm{b}}$ & 2.0 & $181.6^{\mathrm{b}}$ & $0.28^{\mathrm{b}}$ & $0.36^{\mathrm{b}}$ \\
\hline \multicolumn{2}{|c|}{ 14-day $\left(\mathrm{S}_{14}\right)$} & \multicolumn{6}{|c|}{ Irrigation level (I) } \\
\hline & $1917^{\mathrm{a}}$ & $10.8^{\mathrm{a}}$ & $2.4^{\mathrm{a}}$ & $256.5^{\mathrm{a}}$ & $0.38^{\mathrm{a}}$ & 0.45 \\
\hline \multicolumn{2}{|l|}{$\mathrm{I}_{75}$} & $1365^{\mathrm{b}}$ & $9.8^{\mathrm{b}}$ & $2.3^{\mathrm{a}}$ & $223.0^{\mathrm{a}}$ & $0.33^{\mathrm{b}}$ & 0.42 \\
\hline \multicolumn{2}{|l|}{$\mathrm{I}_{50}$} & $863 c$ & $8.7^{\mathrm{c}}$ & $1.8^{\mathrm{b}}$ & $160.8^{\mathrm{b}}$ & $0.25^{\mathrm{c}}$ & 0.39 \\
\hline \multicolumn{8}{|c|}{ S X I } \\
\hline \multirow{3}{*}{ 7-day } & $\mathrm{I}_{100}$ & 2120 & $11.2^{\mathrm{a}}$ & 2.5 & 281.7 & 0.40 & $0.48^{\mathrm{a}}$ \\
\hline & $\mathrm{I}_{75}$ & 1603 & $10.3^{\mathrm{ab}}$ & 2.5 & 258.0 & 0.37 & $0.47^{\mathrm{a}}$ \\
\hline & $\mathrm{I}_{50}$ & 1116 & $10.8^{\mathrm{a}}$ & 1.8 & 196.3 & 0.32 & $0.49^{\mathrm{a}}$ \\
\hline \multirow{3}{*}{ 14-day } & $\mathrm{I}_{100}$ & 1715 & $10.4^{\mathrm{ab}}$ & 2.2 & 231.3 & 0.36 & $0.43^{\mathrm{ab}}$ \\
\hline & $\mathrm{I}_{75}$ & 1127 & $9.2^{\mathrm{b}}$ & 2.0 & 188.0 & 0.29 & $0.37^{\mathrm{b}}$ \\
\hline & $\mathrm{I}_{50}$ & 611 & $6.6^{\mathrm{c}}$ & 1.9 & 125.3 & 0.19 & $0.29^{c}$ \\
\hline \multicolumn{8}{|c|}{ Significance } \\
\hline \multirow{3}{*}{\multicolumn{2}{|c|}{$\begin{array}{l}\text { Irrigation interval (S) } \\
\text { Irrigation level (I) } \\
\text { S X I }\end{array}$}} & $* *$ & $* *$ & ns & $* *$ & $* *$ & $* *$ \\
\hline & & $* *$ & $* *$ & $*$ & $* *$ & $* *$ & $\mathrm{~ns}$ \\
\hline & & ns & $* *$ & ns & ns & $\mathrm{ns}$ & $*$ \\
\hline
\end{tabular}

ns: not significant; *: $\mathrm{P}<0.05 ; * *: \mathrm{P}<0.01$; Lowercase letters indicate significant differences between treatments according to Duncan's test $(\mathrm{P}<0.05)$.

In the graph (Figure 2) showing seed yields obtained from the research treatments, irrigation water amounts, ET and rainfall amount, by comparison to the seed yield of none stress treatment of $\mathrm{S}_{7} \mathrm{I}_{100}$, remarkable yield losses were found at other treatments with reducing water depths. The yield reduction was found as about $20 \%$ in treatments of 14-day irrigation interval and full irrigation $\left(\mathrm{S}_{14} \mathrm{I}_{100}\right)$ and 7 -day irrigation interval with $25 \%$ deficit irrigation treatment $\left(\mathrm{S}_{7} \mathrm{I}_{75}\right)$ by comparison to $\mathrm{S}_{7} \mathrm{I}_{100}$ treatment having maximum yield. In the other word, dry bean had similar response to the 14-day irrigation interval with full irrigation and 7-day irrigation interval with $25 \%$ water deficiency. The yield loss was almost $45 \%$ in treatments having moderate water stress of $\mathrm{S}_{7} \mathrm{I}_{50}$, and $25 \%$ deficit irrigation of $\mathrm{S}_{14} \mathrm{I}_{75}$. The maximum yield loss (-68\%) was obtained from the 14-day irrigation interval with $50 \%$ deficit irrigation $\left(\mathrm{S}_{14} \mathrm{I}_{50}\right)$. These results clearly showed that deficit irrigation at 14-day irrigation interval will causes notable yield losses for dry bean.

In examined the irrigation frequency on yield components of bean for both years, differences between pod number per plant and 1000-seed weight were found statistically significant at $99 \%$ significant level for both the 7 and 14-day irrigation intervals (Table 6, 7). Although seed number per pod for 7 and 14-day irrigation interval at 2013 was found significant, it was none significant statistically for 2014. In general, 14-day irrigation interval resulted important yield reductions for dry bean. 


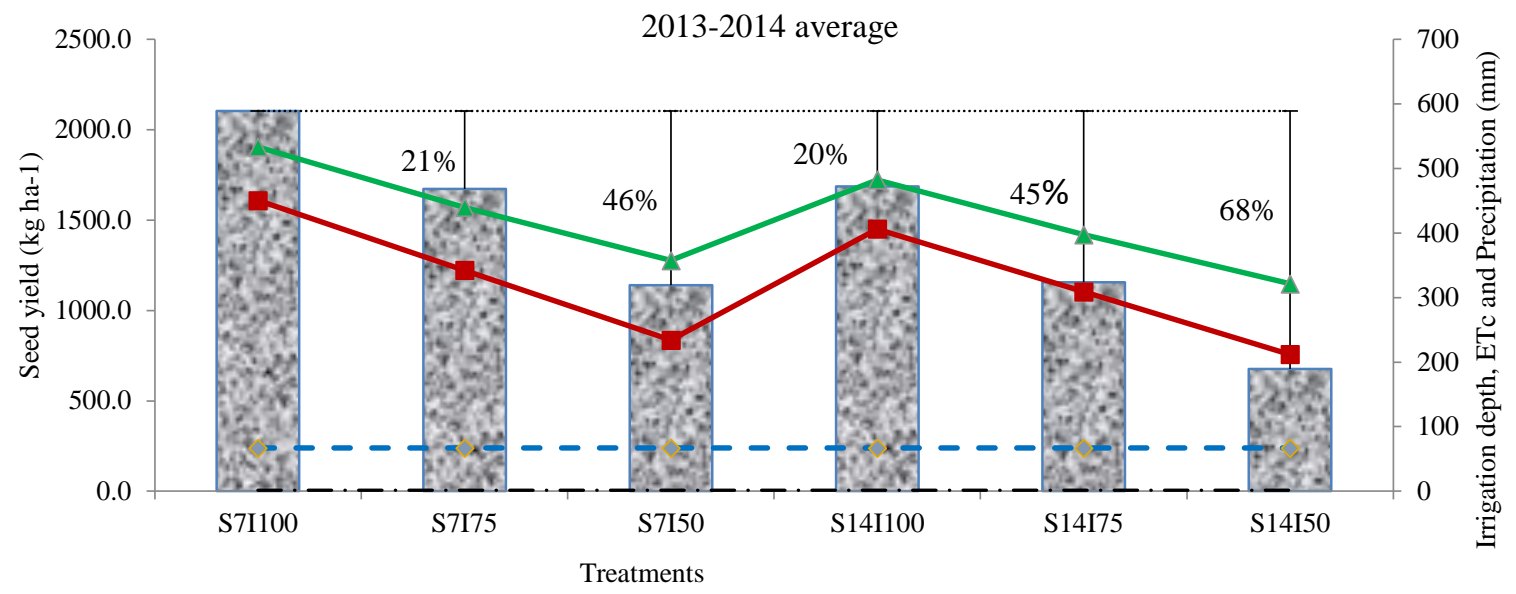

Seed yield $\longrightarrow$ Irrigation water depth $\longrightarrow$ ETc $\quad \rightarrow-$ Precipitation

Figure 2. The total irrigation water depth ( $\mathrm{mm})$, ETc $(\mathrm{mm})$, seed yield (kg ha-1), precipitation $(\mathrm{mm})$, and reductions (\%) in seed yield according to the S7I100 treatment (in combined years).
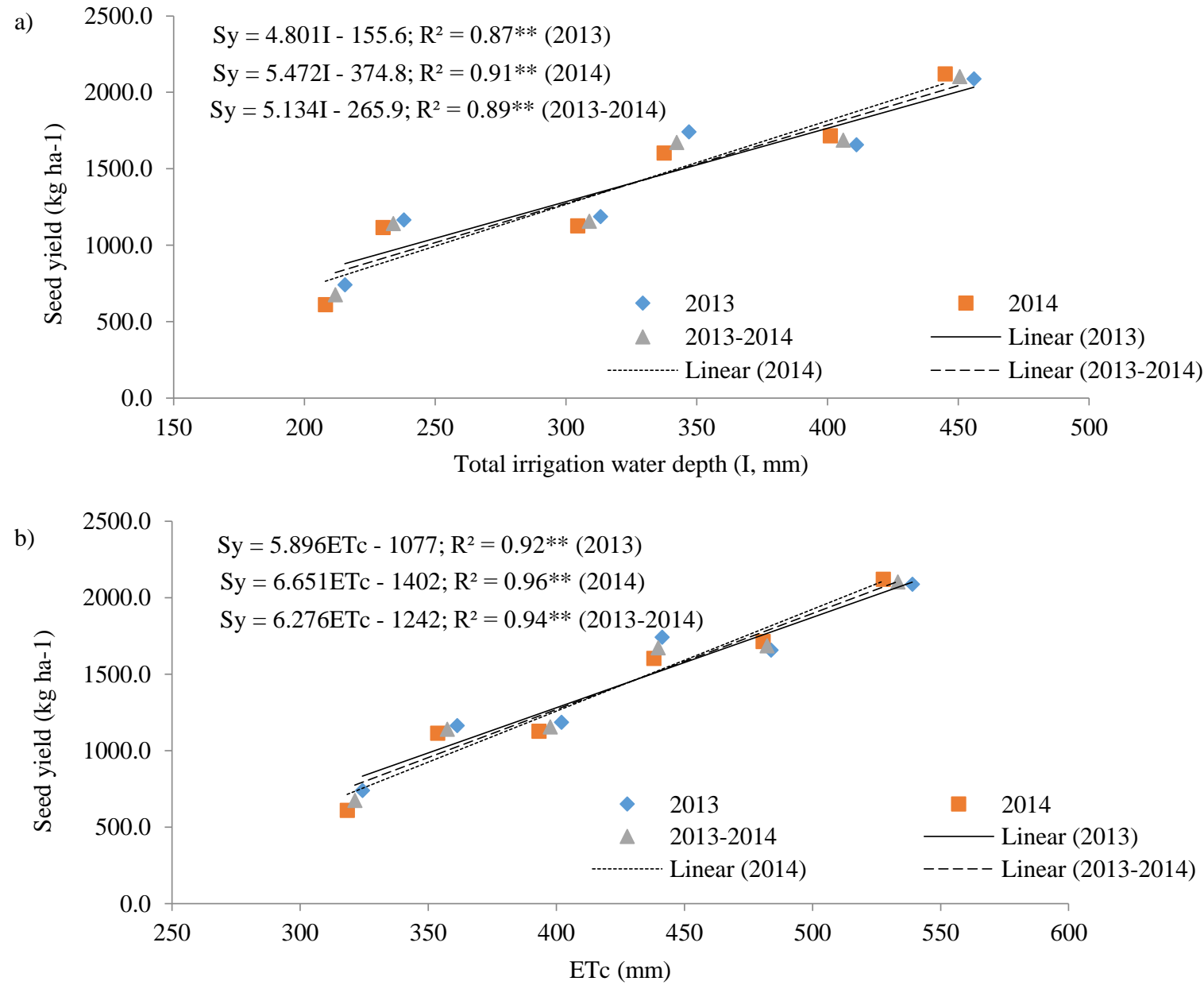

Figure 3. Relationships between seed yield and irrigation water depth (a) and between seed yield and seasonal ETc (b). $(\mathrm{R} 2$, the coefficient of determination; **, $\mathrm{P}<0.01)$

In assessment of irrigation doses affect on yield components for both the experimental years, differences among treatments in respect to the pod number per plant, seed number per pod and 1000-seed weight were found statistically significant (Table 6, 7). In general, the maximum performance for both years in accordance of yield components was found at I100 treatment and increasing the water stress resulted significant reductions at yield components. Similarly, Ünlükara et al. (2018) reported reductions in pod number and seed number under high and moderate water stress conditions. Irrigation interval $\times$ irrigation regimes interaction had only significant effect on pod number per plant, but no significant effect on seed number per pod and 1000-seed weights (Table 6, 7). 


\section{Seed Yield-Water Relationships}

The relationships between seed yields, crop water consumptions (ET), and applied irrigation water amounts obtained from the research treatments for both the experimental years and as an average of years were given as a graphical at Figure 3. Strong linear relationships were found between irrigation water depths, ET and seed yield at $99 \%$ reliability for both the individual years (2013 and 2014) and average of 2-year. The equation and determination coefficient were shown at such graph. A lot of scientist reported linear relationships between water and yield for dry bean (Ünlükara et al., 2018; Yonts et al., 2018; Şehirali et al., 2005).

In current study, the relationships between seed yields and seasonal evapotranspiration were investigated by regression analysis (Figure 4) for determination of yield response factor (ky) of dry bean under arid and semi-arid environments. In combine assessment of data for both the experimental years, ky value of dry bean was calculated as 1.59 , and such finding shows that dry bean is sensitive to the water stress. Similarly some researchers stated ky value as greater than 1 (Suheri et al., 2020; Sezen et al., 2005; Gençoğlan et al., 2006; Doorenbos and Kassam 1979). In contrast to our findings, Abuarab et al. (2020) reported ky value of bean as 0.85 at Egypt. The differences at ky values could be resulted from cultivar, climate characteristics, growing environments and irrigation techniques used.

The results relevant to the water use efficiency (WUE) and irrigation water use efficiency (IWUE) defining as useful ratio from unit water applied and very important indicators in water-yield relationships assessment were presented at Table 6 and 7. In combine evaluations of study years and experimental treatments, WUE value ranged between 0.19 and $0.40 \mathrm{~kg} \mathrm{~m}^{-3}$, and IWUE varied from 0.29 to $0.50 \mathrm{~kg} \mathrm{~m}^{-3}$. The irrigation interval application at both two years had statistically significant effect on both the WUE and IWUE values $(\mathrm{P}<0.01)$. The lengthening the irrigation interval from 7 to 14-day reduced both WUE and IWUE significantly. Efetha et al. (2011) a significant increase in WUE (30\% in 2006 and 50\% in 2007) was found in more frequently irrigated treatments compared to less frequently irrigated treatments. Although different irrigation treatments had no significant effect statistically on WUE, they had significant effect on IWUE. The irrigation interval $\mathrm{x}$ irrigation level interaction had statistically significant effect on IWUE at only 2014. In accordance of the current study findings, increasing irrigation interval from 7-day to 14-day will reduce IWUE as $23 \%$.

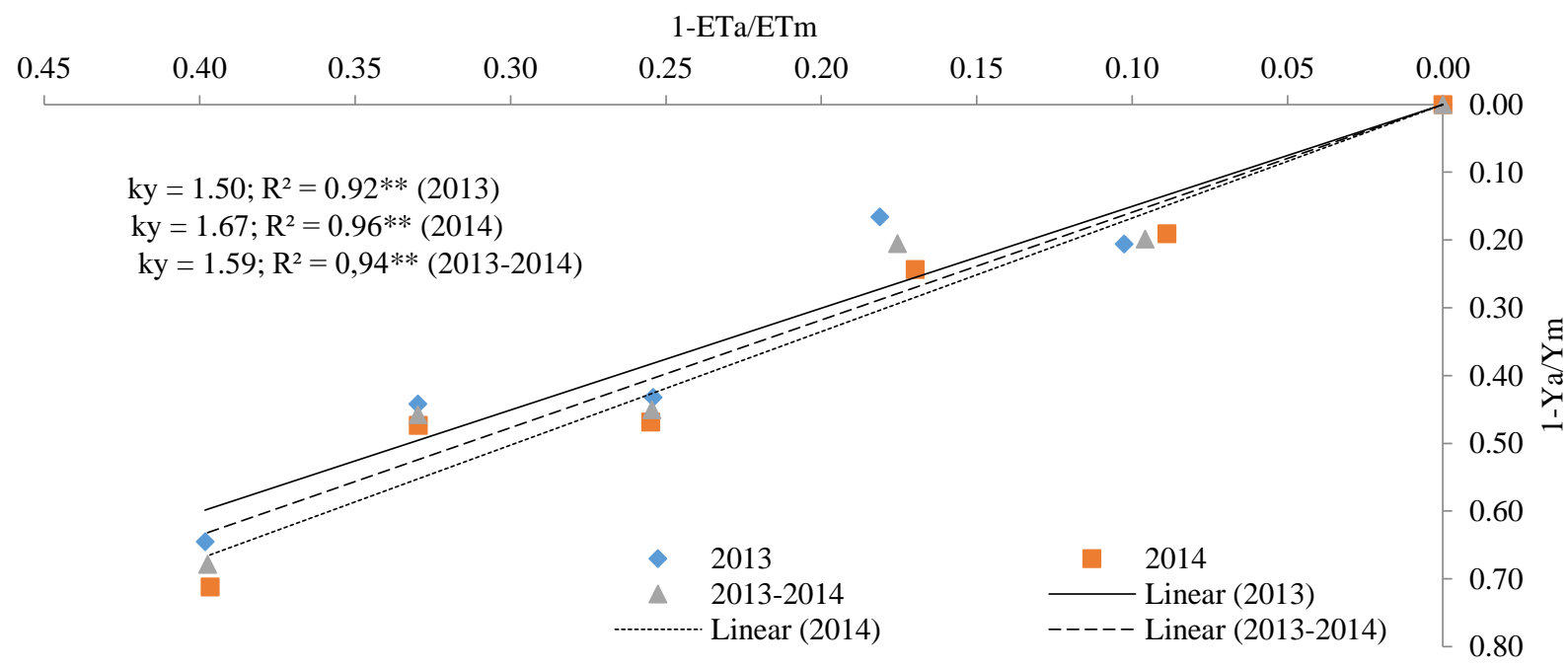

Figure 4. The yield response factor (ky) of dry bean for both individual years and averages of years

\section{Conclusions}

In this study about different irrigation interval and irrigation water depths in dry bean crop, 7-day irrigation interval was found more suitable over 14-day irrigation interval. The farmers have to perform irrigation processes with wide irrigation intervals in particularly summer months which crops need maximum irrigation water in case of farmers performing irrigation by rotation in accordance of programs of cooperative and unions. Farmers having the availability of irrigation via individually have preferred wide irrigation intervals for reducing the labor costs. However, the current study showed that wide irrigation interval of 14-day resulted $28 \%$ yield losses by comparison to the short irrigation interval of 7-day.

The maximum yield was obtained from the treatment having 7-day irrigation interval with full irrigation $\left(\mathrm{S}_{7} \mathrm{I}_{100}\right)$.
None statistical yield difference was detected between 7-day irrigation interval with $25 \%$ deficit irrigation $\left(\mathrm{S}_{7} \mathrm{I}_{75}\right)$ and 14-day irrigation interval with full irrigation $\left(\mathrm{S}_{14} \mathrm{I}_{100}\right)$. In the other word, same amount of yield could be obtained with $15 \%$ water saving by considering $\mathrm{S}_{7} \mathrm{I}_{75}$ treatment instead of $\mathrm{S}_{14} \mathrm{I}_{100}$ treatment. The calculated ky value as 1.59 showed that dry bean crop is not tolerant to the water stress. In assessment of water use efficiency, the maximum WUE and IWUE values were obtained from $S_{7} I_{100}$ and $S_{7} I_{75}$, and from $S_{7} I_{75}$ treatment, respectively. In result, full irrigation is recommended for obtaining high yield, and 7-day irrigation interval with 25\% deficit irrigation is also good solution for water saving particularly at water shortage environments. On the other hand, the planting areas of high water consuming crops such as maize, alfalfa and carrot should be restricted, and crops having low water use such as dry bean could be cultivated widely. 


\section{Acknowledgements}

The author would like to thank Associate Professor Dr. Duran Yavuz and Assistant Professor Dr. Sinan Süheri for their contributions to this study.

\section{References}

Abuarab ME, Hafez SM, Shahein MM, Hassan AM, El-Sawy MB, El-Mogy MM, Abdeldaym EA. 2020. Irrigation scheduling for green beans grown in clay loam soil under a drip irrigation system. Water SA, 46(4), 573-582.

Ahmadi SH, Andersen MN, Plauborg F, Poulsen RT, Jensen CR, Sepaskhah AR, Hansen S. 2010. Effects of irrigation strategies and soils on field grown potatoes: Yield and water productivity. Agricultural Water Management, 97(11), 1923-1930.

Aujla MS, Thind HS, Buttar GS. 2007. Fruit yield and water use efficiency of eggplant (Solanum melongema L.) as influenced by different quantities of nitrogen and water applied through drip and furrow irrigation. Scientia Horticulturae, 112(2), 142-148.

Bourgault M, Madramootoo CA, Webber HA, Stulina G, Horst MG, Smith DL. 2010. Effects of deficit irrigation and salinity stress on common bean (Phaseolus vulgaris L.) and mungbean (Vigna radiata (L.) Wilczek) grown in a controlled environment. J. Agron. Crop Sci. 196 (4), 262-272.

Boutraa T, Sanders FE. 2001. Influence of water stress on grain yield and vegetative growth of two cultivars of bean (Phaseolus vulgaris L.). J. Agron. Crop Sci. 187, 251-257.

Doorenbos J, Kassam AH. 1979. Yield response to water. FAO Irrigation and Drainage Paper, No. 33. Food and Agriculture Organization of the United Nations, Rome, 193 pp.

Efetha A, Harms T, Bandara M. 2011. Irrigation management practices for maximizing seed yield and water use efficiency of Othello dry bean (Phaseolus vulgaris L.) in southern Alberta, Canada. Irrig. Sci. 29, 103-113.

Erdem Y, Arin L, Erdem T, Polat S, Deveci M, Okursoy H, Gültaş HT. 2010. Crop water stress index for assessing irrigation scheduling of drip irrigated broccoli (Brassica oleracea L. var. italica). Agricultural Water Management, 98(1), 148-156.

FAOSTAT. 2021. Agriculture Production. See also: http://www.faostat.fao.org/faostat; (accessed 18.02.2021).

Gençoğlan C, Altunbey H, \& Gençoğlan S. 2006. Response of green bean (P. vulgaris L.) to subsurface drip irrigation and partial rootzone-drying irrigation. Agricultural water management, 84(3), 274-280.

Howell TA, Cuenca RH, Solomon KH. 1990. In: Hoffman, et al. (eds.), Crop yield response. Manage of Farm Irrigation Systems. ASAE, 312 pp.

James LG. 1988. Principles of farm irrigation system design. Wiley, New York, 543 pp.

Lascano RJ and Sojka RE (ed). 2007 Irrigation of Agricultural Crops 2nd edn (Madison, WI: American Society of Agronomy, Inc.)

Munoz-Perea CG, Teran H, Allen RG, Wright JL, Westermann DT, Singh SP. 2006. Selection for drought resistance in dry bean landraces and cultivars. Crop Sci. 46, 2111-2120.

Ninou E, Tsialtas JT, Dordas CA, Papakosta DK. 2013. Effect of irrigation on the relationships between leaf gas exchange related traits and yield in dwarf dry bean grown under Mediterranean conditions. Agric. Water Manage. 116, 235-241.

Satriani A, Loperte A, Soldovieri F. 2015. Integrated geophysical techniques for sustainable management of water resource. A case study of local dry bean versus commercial common bean cultivars. Agric. Water Manage. 162, 57-66.

Schwartz HF, Brick MA (Eds.). 2015. Dry Bean Production \& Pest Management, 3rd edition. Cooperative Extension Resource Center Colorado State University

Şehirali, S., Erdem, T., Erdem, Y., \& Kenar, D. 2005. Damla Sulama Yöntemi ile Sulanan Fasulyenin Phaseolus vulgaris L. Su Kullanım Özellikleri. Journal of Agricultural Sciences, 11(02), 212-216.
Sezen MS, Yazar A, Canbolat M, Eker S, Celikel G. 2005. Effect of drip irrigation management on yield and quality of field grown green beans. Agric. Water Manage. 71, 243-255.

Simsek M, Comlekcioglu N, Ozturk I. 2011. The effects of the regulated deficit irrigation on yield and some yield components of common bean (Phaseolus vulgaris L.) under semi-arid conditions. Afr. J. Biotechnol. 10 (20), 4057-4064.

Süheri S, Hussein NMH, Kurtar ES, Yavuz N, Dal Y. 2020. Determination of Yield and Quality of Different Snap Bean Varieties Under Deficit Irrigation. Tekirdağ Ziraat Fakültesi Dergisi, 17(2), 252-263.

Topak R, Acar B, Süheri S. 2009. Drip and sprinkler irrigation of dry bean (Phaseolus vulgaris L.) in the Konya basin, Turkey. Philippine Agricultural Scientist, 92(2), 186-192.

Topak R, Acar B, Uyanöz R, Ceyhan E. 2016. Performance of partial root-zone drip irrigation for sugar beet production in a semi-arid area. Agricultural Water Management, 176, 180-190.

TUIK. 2021. Turkish Statistical Institute. See also: http://www.tuik.gov.tr; (accessed 24.03.2021).

Ucar Y, Kadayifci A, Yilmaz HI, Tuylu GI, Yardimci N. 2009. The effect of deficit irrigation on grain yield of dry bean (Phaseolus vulgaris L.) in semiarid regions. Span. J. Agric. Res. 7, 474-485.

Ünlü M, Kanber R, Şenyigit U, Onaran H, Diker K. 2006. Trickle and sprinkler irrigation of potato (Solanum tuberosum L.) in the Middle Anatolian Region in Turkey. Agricultural water management, 79(1), 43-71.

Ünlükara A, Aksu Ö, Arslan M. 2018. Kuru fasulyenin (Phaseolus vulgaris L.) Farklı Ekim Sıklığı ve Su Stresi Koşullarında Verim ve Kalite Kriterlerinin Belirlenmesi. Uluslararası Su ve Çevre Kongresi (22-24 Mart 2018), BursaTürkiye, 877-885.

Wakrim R, Wahbi S, Tahi H, Aganchich B, Serraj R. 2005. Comparative effects of partial root drying (PRD) and regulated deficit irrigation (RDI) on water relations and water use efficiency in common bean (Phaseolus vulgaris L.). Agric. Ecosyst. Environ. 106 (2), 275-287.

Yavuz D and Yavuz N. 2021. Can agricultural drought be prevented or is it the inevitable end? 3. International African Conference on Current Studies. 27-28 February, 2021. https://www.africansummit.org/ Abomey-Calavi, Benin. 417-426.

Yavuz D, Seymen M, Süheri S, Yavuz N, Türkmen Ö, \& Kurtar ES. 2020. How do rootstocks of citron watermelon (Citrullus lanatus var. citroides) affect the yield and quality of watermelon under deficit irrigation? Agricultural Water Management, 241, 106351.

Yavuz D, Seymen M, Yavuz N, Çoklar H \& Ercan M. 2021. Effects of water stress applied at various phenological stages on yield, quality, and water use efficiency of melon. Agricultural Water Management, 246, 106673.

Yavuz D, Yavuz N, Seymen M, Türkmen Ö. 2015. Evapotranspiration, crop coefficient and seed yield of drip irrigated pumpkin under semi-arid conditions. Sci. Horti. 197, 33-40.

Yavuz N, Çiftçi N, Yavuz D. 2019. Effects of different irrigation interval and plant-pan coefficient applications on yield and quality parameters of oil sunflower grown in semi-arid climatic conditions. Arabian Journal of Geosciences, 12(22), 1-11.

Yavuz N. 2021. Can grafting affect yield and water use efficiency of melon under different irrigation depths in a semi-arid zone?. Arabian Journal of Geosciences, 14(12), 1-14.

Yonts CD, Haghverdi A, Reichert DL, Irmak S. 2018. Deficit irrigation and surface residue cover effects on dry bean yield, in-season soil water content and irrigation water use efficiency in western Nebraska high plains. Agricultural Water Management, 199, 138-147.

Yonts CD, Nuland DS. 1997. Irrigating dry beans. University of Nebraska, Cooperative Extension. NebGuide no. G84-686-A. 